Jurnal Bisnis dan Manajemen, Volume 22, No. 2, September 2021, p. 67-80

\title{
THE ROLE OF EMPLOYEE CREATIVITY AS A MEDIATOR BETWEEN HIGH- PERFORMANCE WORK PRACTICE, INNOVATIVE BEHAVIOR, AND SUSTAINABLE COMPETITIVE ADVANTAGE IN THE HOTEL INDUSTRY
}

\author{
Sarfilianty Anggiani' ${ }^{1}$ Tiurida Lily Anita² \\ ${ }^{1}$ Universitas Trisakti, Indonesia \\ ${ }^{2}$ Bina Nusantara University, Indonesia
}

\begin{abstract}
This study aims to find if employee creativity has a significant impact as a mediator to High-performance work practice, innovative behavior, and sustainable competitive advantage in the Hotel industry during the pandemic. This study was conducted by conducting observations and surveys to Four Stars Hotels around the Jakarta area. Population and samples were taken from employees who work in the Four stars Hotel since the hotel was started operating again around December 2020. This research was conducted in a quantitative approach. The data collection instrument using a questionnaire with a sampling technique is purposive sampling. The analysis technique, namely path analysis using SMART PLS, is carried out to show whether employee creativity has an impact as a mediator to high-performance work practice, innovative behavior, and sustainable competitive advantage. The result shows that Employee creativity has an impact as a mediator to high-performance work practice, innovative behavior, and sustainable competitive advantage. Innovative behavior has no direct impact on sustainable competitive behavior.
\end{abstract}

Keywords: High-Performance Work Practice, Employee Creativity, Innovative Behavior, Sustainable Competitive Advantage, Hotel Industry.

\section{PERAN KREATIVITAS KARYAWAN SEBAGAI MEDIATOR PRAKTIK KERJA KINERJA TINGGI, SIKAP INOVATIF, DAN KEUNGGULAN BERSAING INDUSTRI PERHOTELAN}

\begin{abstract}
ABSTRAK
Penelitian ini bertujuan untuk menemukan apakah kreativitas karyawan memiliki dampak besar sebagai mediator terhadap praktik kinerja tinggi, perilaku inovatif, dan keunggulan kompetitif yang berkelanjutan di industri Hotel selama pandemi. Penelitian ini dilakukan dengan melakukan observasi dan survei ke Hotel Bintang Empat di sekitar wilayah Jakarta. Populasi dan sampel diambil dari karyawan yang bekerja di Hotel Bintang Empat sejak hotel ini mulai beroperasi lagi sekitar Desember 2020. Penelitian ini dilakukan dengan pendekatan kuantitatif. Instrumen pengumpulan data menggunakan kuesioner dengan teknik pengambilan sampel adalah purposive sampling. Teknik analisis, yaitu analisis jalur menggunakan SMART PLS, dilakukan untuk menunjukkan apakah kreativitas karyawan berdampak sebagai mediator terhadap praktik kerja berkinerja tinggi, perilaku inovatif, dan keunggulan kompetitif yang berkelanjutan. Hasil penelitian menunjukkan bahwa kreativitas Karyawan berdampak sebagai mediator terhadap praktik berkinerja tinggi, perilaku inovatif, dan keunggulan kompetitifyang berkelanjutan. Perilaku inovatif tidak berdampak langsung pada perilaku kompetitif yang berkelanjutan.
\end{abstract}

Kata-kata Kunci: High-Performance Work Practice, Employee Creativity, Innovative Behavior, Sustainable Competitive Advantage, Hotel Industry.

Korespondensi: Tiurida Liy Anita, S.ST.Par.,MM. Universitas Bina Nusantara. Jln. KH Syahdan No 9 Kemanggisan, Jakarta, 11480. Email: tiurida.anita@binus.ac.id. 
Jurnal Bisnis dan Manajemen, Volume 22, No. 2, September 2021, p. 67-80

\section{INTRODUCTION}

The hospitality industry, especially hotels, is one of the few businesses severely affected by the Covid19 pandemic. Because during the pandemic, people are encouraged to minimize outdoor activities and not to go out if there is no urgency. Also, the regulation of travel restrictions, strict requirements to use public transportation, to the growing case of infection make many people think twice about traveling far (Luthfia Ayu, 2020). This makes the industry in the field of hospitality must re-arrange their company's strategy, especially on strategic management issues, to maintain business sustainability. Strategic management that needs to be considered is related to the economic dimension because it aims to give the company sustainable competitive advantages (Hill \& Jones, 2009).

Sustainable competitive advantages are essential in the hotel industry, whose survival depends on many factors (Salguero et al., 2019). These factors include employee creative behavior, which helps any organization to develop its business (Vasudevan, 2013). Organizations need creativity to survive in a changeable environment (J. M. George, 2007). To anticipate the current situation and better prepare to address the situation, organizations in the hotel industry must have in the ranks of their creative employees the ability to convert information to products and process innovations accordingly (Salguero et al., 2019).
The hospitality industry is a highly developed business, focusing on the important aspects that are guests, as the main source of income. This aspect is a unique aspect of the hospitality industry. With the characteristics of performance development in terms of skill, knowledge, and attitude, hotel employees are prepared to interact directly and indirectly with guests. So, employees are in need to develop their creativity in handling guests. The development of individual skills and creativity plays a very important role in improving employee behavior as it leads to better employee performance and guest satisfaction (Awasthi et al., 2020). Creativity is essential among employees in the organization because they must think creatively and balance their emotions in order to solve organizational problems, in this case, any problems that have a connection to guests who visit the hotel.

Human resource practice in the organization is very important because it helps the work system to have high performance. Some of the human resource practices that improve the performance of the system and should be embraced in the organization include the use of the team-based organizational structures which take into consideration of the individual workers specially HPW to enhance the individual creativity to solve problems that leads to innovative behavior and sustainable competitive advantage. 
Jurnal Bisnis dan Manajemen, Volume 22, No. 2, September 2021, p. 67-80

This study will focus on the role of employee creativity, as a mediator to highperformance work practice and innovative behavior of hotel's employee. This study will empirically try to prove the effect of the employee creativity as the mediator and does it will make an impact on sustainable competitive advantage in the hotel industry.

\section{LITERATURE REVIEW}

High-Performance Work Practice (HPW) and Employee Creativity (EC)

The performance itself is defined as the behavior on how a target is achieved (Armstrong, M. \& Taylor, 2014). Process of performance orientation's purpose is to ensure that every process on the organizational directly in place for ensuring that the productivity of employees is in their maximum value, both the team and the organization itself. In a short definition, performance is the things done by employees to maximize their productivity (Luthans, 2005).

To achieved High-performance work practices (HPW), hotel employees need a competence-based perspective. This competence could help to enhance organizational creativity in any circumstances with a particularly important effect (Jeong \& Shin, 2019). The perspective would lead the organizational learning from input in organizational learning to outputs in human resources management (HRM) (Colbert \& Colbert, 2004). With the main focus in terms of developing employee creativity. From many studies, HRM can be directly used as a facilitator of learning and creative performance, because programs in HRM can be a useful tool in building social platforms where employees as individuals are encouraged to collectively learn from each other as a team (Kang, Morris \& Snell, 2007). HPW that occur, tend to directly engage employees to proactively interact and learn from each other so that they can bring out their creative side (Hirst et al., 2009). To measure HPW we proposed some indicators, which are: training, empowerment, selective staffing, rewards, and teamwork (Boshoff, C. and Allen, 2000). Therefore, we proposed our first hypothesis as follows.

H1. High-performance work practices (HPW) have a significant impact on employee creativity.

\section{Innovative behavior (IB) and Employee Creativity (EC)}

Innovative behavior is also needed by the organization to support employee creativity. This is important for hotel employees as they must have direct interaction with the guest. Sometimes, they have to face many repeating guests who stay at the hotel for few days. Innovative behavior can be interpreted as an initiative of employees in understanding new processes, new products, new markets, or a combination of these three things into the organization. These initiatives can be inspired by market demand or by technological advances supporting work. The innovative behavior of employees may not be appreciated by top management, and may not even be known by organizational leaders. The process of change that occurs in employees with innovative behavior 
Jurnal Bisnis dan Manajemen, Volume 22, No. 2, September 2021, p. 67-80

may be gradual or may also have a profound effect directly on the organization. The result can be a spin-off: new products, new markets, or total failure to the company (AMO \& KOLVEREID, 2005).

Many researchers consider that IB and creativity are interrelated because the position of creativity in front will be closed with the IB behind, or seen as the initial and final stage ( $\mathrm{Li} \&$ Hsu, 2016). Creative employees will usually rely on their abilities when their work environment is restrictive, or not conducive. Creativity will stand as an employee's resource that will be useful in showing off the IB. Based on that, Creativity will be a perfect mediator of HPW to IB. IB review will be higher when creative employees benefit from within a conducive organization such as HPW (Bakker \& Demerouti, 2007). IB may be assessed by metrics such as coming up with innovative and creative ideas at work, attempting to convince others of creative ideas, seeking new service approaches, strategies, or techniques, providing a suitable strategy for implementing new ideas, attempting to obtain the funding and resources required to introduce innovations, and being considered a creative member of the team. (Monica Hu et al., 2009). Based on this, our second hypothesis is as follows.

$\mathrm{H} 2$. Innovative behavior has a significant impact on employee creativity.

\section{Employee Creativity and Sustainable Competitive Advantage}

Various ideas, thoughts, and skills can be connected and reorganized in a way that they can be an organizational resource to improve problemsolving skills (Gant J., 2002). HPW activities, according to Colbert (2004), promote spontaneous social learning among workers, which benefits by growing innovation by reducing boundaries, such as a lack of social capital (Gant J., 2002) and bridging weak bonds (Evans, W. R., \& Davis, 2005), democratization process-for example, employee empowerment (Evans, W. R., \& Davis, 2005), energized the model and coherent language (Mahdi et al., 2015) as well as encouraging experience and learning capacity of employees (Chang, 2011). In short, employee creativity can lead organizations to have a sustainable competitive advantage among their competitors. Employee innovation can be measured by suggesting new approaches to accomplish objectives or goals.

To boost results, comes up with fresh and realistic ideas. Looks for emerging technology, methods, strategies, and/or product concepts, and makes suggestions for how to improve quality. Employee Creativity is a great chance to get new ideas, and employee would never be afraid to try new things, promotes and champions ideas to others, displays ingenuity on the job when permitted, creates appropriate plans and schedules for the introduction of new ideas, always has new and inventive ideas, comes up with creative solutions to problems, and proposes new ways of 
Jurnal Bisnis dan Manajemen, Volume 22, No. 2, September 2021, p. 67-80

conducting work tasks (Jennifer M. George \& Zhou, 2001). Therefore, our third hypothesis is as follows.

H3. Employee creativity has a significant impact on sustainable competitive advantage (SCA).

\section{High-Performance Work practice and Sustainable Competitive Advantage}

Competitive advantage is defined as the strategic advantage the company has over its competitors in its competitive industry (Wu \& Chen, 2012). The Resource-based view (RBV) point of view looks at resources at the value, rare, inimitable, and nonsubstitutable values, and the ability of a company to maintain the sustainability of the company's competitive value. Resources in question are human resources, including the organization's physical and intangible capital. Unlike physical assets that are easy to copy, companies must maintain human capital in the company, including ensuring that all areas tacit, heterogeneous, and immobile as possible. HPW represents a series of RBV practices that enable the acquisition of unique intellectual capital in human resources, as well as the development of social capital and the application of HR capabilities to improve practices so that high-performance work (HPW) can be achieved. Furthermore, the relational view of competitive advantage suggests that HPW can be a source of competitive advantage. Competitive advantage is measured by four items that assess whether the company's products offer unique benefits, have superior quality and distinct advantages, and are more advanced than their competitors (Wu \& Chen, 2012). Based on that, this study proposed hypothesis as follows.

H4. High-performance work (HPW) practices have a significant impact on sustainable competitive advantage (SCA).

\section{Innovative Behavior and Sustainable Competitive Advantage}

Employees who exhibit IB will produce superior utility for both consumers and the company, allowing it to stand out among competitors. CA's value can be produced by IB, as long as the attainment and sustainability impetus are present (Elidemir et al., 2020). Based on this, we proposed our next hypothesis as follows.

H5. Innovative Behavior (IB) has a significant impact on sustainable competitive advantage.

\section{Employee Creativity (EC) as a moderator}

Employee creativity refers to employees' ability to come up with new ideas or solutions to problems. According to the literature, creativity is an intangible, scarce, inimitable, and nonsubstitutable resource that can be a valuable source of competition and competitive advantage for businesses (Sulaiman et al., 2015). HPW trough training provides knowledge, skills improvement, and learning that foster employee unique tacit, inimitable human capital, which in turn develop potential creative capacities to support competitiveness around the business, and thereby innovative work outcomes (Elidemir et al., 2020).

From this premise, creativity will likely vary from person to person, despite the dynamics 
Jurnal Bisnis dan Manajemen, Volume 22, No. 2, September 2021, p. 67-80

of the surrounding contextual factors. Specifically, regardless of whether or not elements of the workplace environment encourage creativity, an employee exhibiting a greater extent of these individual creativity-enhancing characteristics would also be prone to show higher creative abilities. Ultimately, service organizations that succeed in securing, retaining, and managing the services of highly creative individuals would be strategically better off than their counterparts with employees with lesser creative abilities.

H6: Employee creativity (EC) has a significant role as a moderator for High-Performance Work Practices (HPW), Innovative Behavior (IB), and Sustainable Competitive Advantage (SCA).

\section{METHODS}

Human resource management literature in the field of hospitality recommends that star hotels must take the opportunity to research in the field of human resources (HR) to reflect the development of human resources in the field of hospitality (Liu, 2017). This research is quantitative research by surveying to collect data online. The survey was conducted online and distributed questionnaires to 125 respondents working in 4-star hotels in Jakarta. Sampling techniques are done using purposive sampling techniques. The number of questionnaires returned was 100 questionnaires. This is sufficient considering that according to Heir, that the minimum sample required can be calculated by multiplying the total number of relationship lanes in the study multiplied by 10 , this means that 5 lanes of relationship multiplied by 10 , i.e. 50 samples (Hair et al., 2019). Analysis Techniques used in this study are using SEM-PLS. The sample size is determined based on several criteria, namely level of significance (1\%), coefficient of determination (5\%). High-performance work practice (HPW) is measured using indicators of training, empowerment, selective staffing, rewards, and teamwork. Innovative behavior (IB) is measured using indicators from $\mathrm{Hu}$, Horng, and Sun as many as 6 items (Monica Hu et al., 2009). Employee creativity (EC) is measured by 13 indicator items adapted from George and Zhoe's research (Jennifer M. George \& Zhou, 2001). And, for sustainable competitive advantage (SCA) will be taken from $\mathrm{Wu}$ and Chen research as many as 4 items indicator (Wu \& Chen, 2012).

\section{RESULTS AND DISCUSSION}

The results of demographic are as follows: respondent who filled out the questionnaire consisted of 54 respondents (54\%) male and 46 respondents (46\%) women, with the age range of the majority of respondents are in the age range of 25 - 34 years of 51 respondents. The working period of the most respondents is in the working period of $<5$ years as many as 57 respondents or $57 \%$, and the field of work of the most respondents is in the food \&beverage section as much as 41 respondents or $41 \%$.

According to Ghozali (2015), assessing the

Fit Model of a study in PLS data processing 
Jurnal Bisnis dan Manajemen, Volume 22, No. 2, September 2021, p. 67-80

requires two phases. The analysis or assessment of measurement models, as well as the analysis of structural models, are among these steps. Testing the validity and reliability of research instruments is used to analyze measurement models (Ghozali, I., \& Latan, 2015).

There are three standards for assessing validity and reliability (Outer Model) while using data analysis techniques with Smart-PLS: convergent validity, average variance derived (AVE), discriminant validity, and composite reliability.

\section{Convergent validity}

The correlation between score items/component scores calculated with Smart-PLS software is used to determine the convergent validity of measurement models with reflexive indicators. When the cross-loading value with the construct measured is 0.7 , the size of individual reflexive indicators is said to be large. This study will be used cross-loading limit of 0.7 . So, for items whose cross-loading value is below 0.7 will be excluded from the next analysis.

Table 1. Outer Loadings

\begin{tabular}{|c|c|c|c|c|}
\hline & EC & HPW & IB & SCA \\
\hline EC1 & 0.819 & & & \\
\hline EC11 & 0.809 & & & \\
\hline EC2 & 0.728 & & & \\
\hline EC3 & 0.848 & & & \\
\hline EC4 & 0.852 & & & \\
\hline EC5 & 0.865 & & & \\
\hline EC6 & 0.870 & & & \\
\hline EC8 & 0.744 & & & \\
\hline HPW1 & & 0.846 & & \\
\hline HPW2 & & 0.852 & & \\
\hline
\end{tabular}

\begin{tabular}{llll}
\hline HPW3 & 0.735 & & \\
HPW4 & 0.724 & & \\
HPW5 & 0.793 & & \\
IB2 & & 0.863 & \\
IB3 & & 0.867 & \\
IB4 & 0.793 & \\
IB5 & 0.806 & \\
IB6 & 0.827 & \\
SCA2 & & 0.835 \\
SCA3 & & 0.811 \\
SCA4 & & & 0.813 \\
\hline SOIrCe: Result Of PrOcessing Data & 2021
\end{tabular}

Source: Result of Processing Data, 2021.

The results of processing using Smart-PLS can be seen in table 1 . The score for each construct indicator meets the required convergent validity of 0.7 . The score for each construct indicator ranges from 0.72 to 0.86 . Thus, the indicators used have adequately described each construct or variable to be measured.

\section{Average Variance Extracted (AVE)}

In the analysis of confirmatory factors, the average percentage of AVE values between items or indicators of a set of latent constructs is a summary of the convergent indicator. A good construct is if the AVE value is $\geq 0.5$.

Table 2. Score of AVE

\begin{tabular}{lc}
\hline & $\begin{array}{c}\text { Average Variance } \\
\text { Extracted (AVE) }\end{array}$ \\
\hline EC & 0.670 \\
HPW & 0.627 \\
IB & 0.691 \\
SCA & 0.672 \\
\hline
\end{tabular}

Source: Result of Processing Data, 2021.

From table 2 above can be seen that the AVE value for each construct, namely highperformance Work (HPW), Innovative Behavior (IB), Employee Creativity (EC), and Sustainable 
Jurnal Bisnis dan Manajemen, Volume 22, No. 2, September 2021, p. 67-80

Competitive Advantage (SCA) has an AVE value between 0.627 to 0.691 . Thus, the value of each construct with its indicator is good because it has met the minimum value requirement, which must be higher than 0.5 .

\section{Discriminant Validity}

Discriminate Validity is a test of how distinct a construct is from other constructs. A high discriminant validity value indicates that a construct is special and capable of capturing the phenomenon being evaluated. Comparing AVE square root values (AVE) with correlation values between constructs is one way to measure discriminant validity. With SmatPLS, discriminant validity is obtained by looking at the value of Cross Factor Loadings and Fornell lacker criterion.

Table 3. Cross Factor Loadings

\begin{tabular}{lcccc}
\hline & \multicolumn{1}{l}{ EC } & HPW & \multicolumn{1}{l}{ IB } & \multicolumn{1}{l}{ SCA } \\
\hline EC1 & 0.819 & 0.026 & 0.715 & 0.065 \\
EC11 & 0.809 & 0.153 & 0.670 & 0.128 \\
EC2 & 0.728 & 0.064 & 0.591 & 0.064 \\
EC3 & 0.848 & -0.023 & 0.697 & 0.110 \\
EC4 & 0.852 & -0.002 & 0.689 & 0.077 \\
EC5 & 0.865 & -0.088 & 0.715 & -0.085 \\
EC6 & 0.870 & -0.065 & 0.748 & -0.038 \\
EC8 & 0.744 & 0.090 & 0.659 & 0.042 \\
HPW1 & 0.066 & 0.846 & 0.053 & 0.545 \\
HPW2 & -0.093 & 0.852 & -0.001 & 0.570 \\
HPW3 & 0.010 & 0.735 & -0.056 & 0.425 \\
HPW4 & 0.125 & 0.724 & 0.133 & 0.414 \\
HPW5 & -0.001 & 0.793 & 0.107 & 0.512 \\
IB2 & 0.690 & 0.057 & 0.863 & 0.044 \\
IB3 & 0.716 & 0.107 & 0.867 & 0.081 \\
IB4 & 0.679 & -0.097 & 0.793 & -0.094 \\
IB5 & 0.731 & 0.088 & 0.806 & 0.122 \\
IB6 & 0.671 & 0.080 & 0.827 & 0.125 \\
SCA2 & 0.023 & 0.496 & 0.010 & 0.835 \\
\hline & & & &
\end{tabular}

\begin{tabular}{ccccc}
\hline SCA3 & 0.065 & 0.503 & 0.097 & 0.811 \\
SCA4 & 0.042 & 0.544 & 0.061 & 0.813 \\
\hline \multicolumn{7}{l}{ Source: Result of Processing } & Data, 2021
\end{tabular}

Table 4. Fornel-Lacker Criterion

\begin{tabular}{lllll}
\hline & EC & HPW & IB & SCA \\
\hline EC & 0.818 & & & \\
HPW & 0.020 & 0.792 & & \\
IB & 0.840 & 0.059 & 0.832 & \\
SCA & 0.053 & 0.629 & 0.069 & 0.820 \\
\hline
\end{tabular}

Source: Result of Processing Data, 2021

Based on the table 3 and 4, the cross-factor loadings and Fornel-Lacker Criterion values of each construct are higher than the values of each other. Thus, judging from the differentiating validity value, each construct is a unique variable, and different from other constructs or variables because it has a higher value when faced with other variables.

\section{Construct reliability}

Methods for assessing reliability can be determined by a composite reliability value greater than 0.7. Also, the reliability of the construct can be seen from the results of the Cronbach Alpha test. These results can be seen from the following table.

\section{Table 5. Cronbach Alpha \& CR}

\begin{tabular}{lrrr}
\hline & $\begin{array}{c}\text { Cronbach's } \\
\text { Alpha }\end{array}$ & rho_A & $\begin{array}{r}\text { Composite } \\
\text { Reliability }\end{array}$ \\
\hline EC & 0.929 & 0.931 & 0.942 \\
HPW & 0.851 & 0.863 & 0.893 \\
IB & 0.888 & 0.889 & 0.918 \\
SCA & 0.757 & 0.757 & 0.860 \\
\hline
\end{tabular}

Source: Result of Processing Data, 2021.

From the table 5 above all indicators in the study can be said to be good, because it has a 
Jurnal Bisnis dan Manajemen, Volume 22, No. 2, September 2021, p. 67-80

composite reliability value and Cronbach alpha value greater than 0.7. All values or scores of each variable are above the value of $0.75-0.94$. That is, from the results of this reliability test that each variable has a very high level of reliability.

Furthermore, the structural models are tested or measured in the second stage of study, also known as inner model measurements. The relationship between the build, the significance value, and the R-Square of the research model was investigated using inner model or structural model testing. R-Square is used to assess structural models for t-test based constructs and the importance of structural path parameter coefficients.

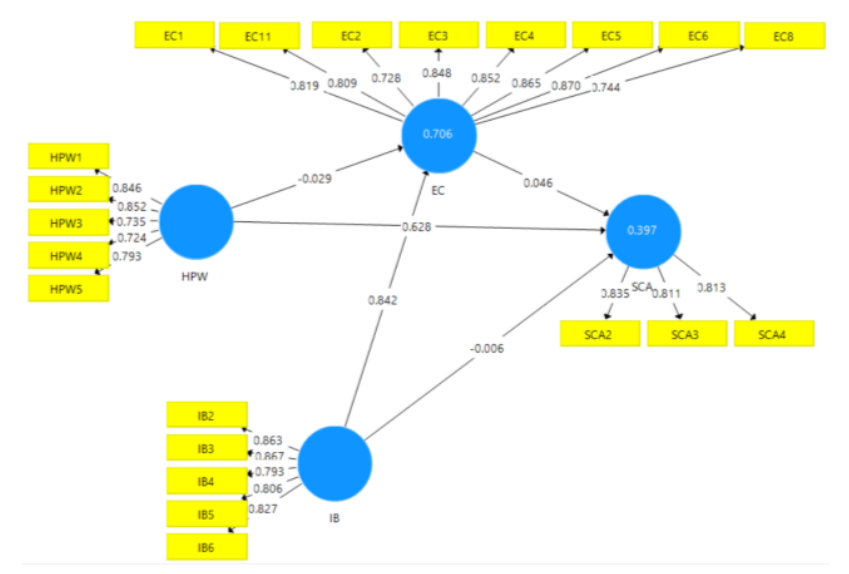

Figure 1. Structural Model

Source: Result of Processing Data, 2021

Figure 1 is a structural model that shows the influence of HPW and IB on SCA through EC by employees of 4-star hotels. From the picture, the $\mathrm{R}-$ Square value of EC is 0.706 . This means the influence of high-performance Work practice affects Employee creativity by $70.6 \%$. The remaining $29.4 \%$ was influenced by other factors not discussed in the study. Besides, the R-Square value of Sustainable competitive advantage is influenced by employee creativity of 0.397 . This means that employee creativity affects sustainable competitive advantage by $39.7 \%$, the remaining $60.3 \%$ is influenced by other factors.

The next analysis is to perform relationship analysis measurements by calculating the coefficient path value for each path. This analysis is done by first resampling using bootstrapping method against the sample. Bootstrapping is intended to minimize the problem of abnormal research data. Based on the data after bootstrapping, obtained data relationship between variables as follows.

Table 6. Path Coefficients

\begin{tabular}{lccr}
\hline & $\begin{array}{c}\text { Original } \\
\text { Sample } \\
(\mathbf{O})\end{array}$ & $\begin{array}{c}\text { Sample } \\
\text { Mean } \\
(\mathbf{M})\end{array}$ & $\begin{array}{c}\text { T Statistics } \\
(\mid \mathbf{O} / \mathbf{S T D E V})\end{array}$ \\
\hline EC -> SCA & 0.046 & 0.042 & 2.274 \\
HPW -> EC & 0.029 & 0.031 & 4.489 \\
HPW -> SCA & 0.628 & 0.637 & 11.884 \\
IB -> EC & 0.842 & 0.837 & 15.982 \\
IB -> SCA & 0.006 & 0.016 & 0.040 \\
\hline Source: Result of Processing Data, 2021.
\end{tabular}

The results of measurement or testing of the relationship between HPW to EC showed path coefficient values of 0.029 with $\mathrm{T}$ statistics of 4,489 . The $\mathrm{t}$ table value is 1.98 , which means there is a relationship between HPW and EC. So H1 is accepted.

High-performance work practice (HPW) has a direct relationship with employee creativity. This is because employees consider HPW's activities to be part of employee creativity. The activities of carrying out training 
Jurnal Bisnis dan Manajemen, Volume 22, No. 2, September 2021, p. 67-80

undertaken by hotel management, empowerment, correct staffing, rewards, and teamwork that has been done by hotel management are considered quite supportive in facilitating freedom of creativity among employees. This study support the previous study conducted by Jeong and Shin proposing that HPW led to more employee creativity when a company is more likely to encourage employees to communicate and learn from one another in order to become more innovative (Jeong \& Shin, 2019).

From table 6, IB to EC showed path coefficient values of 0.842 with $\mathrm{T}$ statistics of 15,982 . The t-table value is 1.98 , which means there is a relationship between IB and EC. So H2 is accepted. Innovative behavior has a direct effect on employee creativity. This study also confirmed the previous study conducted by Elidemir et al, that employees tend to feel freedom with innovative behavior ideas in carrying out work. So it triggers creativity without being burdened with the limitations that exist in each department (Elidemir et al., 2020).

The measurement of EC to SCA relationship with path coefficient value of 0.046 and $t$ statistic of 2.274, also identified a direct relationship between EC and SCA. So H3 is accepted. In the relationship between employee creativity to sustainable competitive advantage, it is concluded that there is a relationship between employee creativity to sustainable competitive advantage despite having a relationship of $39.7 \%$. Employee freedom triggers innovations in working using appropriate and up-to-date methods that will be able to make the four-star hotel industry able to compete with other hotels on an ongoing basis (Connolly \& McGing, 2007).

HPW's measurement of SCA and IB against SCA with path coefficient values of 0.628 and 0.006 and $t$ statistic values of 11,884 and 0.040 indicates that there is a direct relationship between HPW to SCA, so H4 is accepted, but there is no direct relationship between IB to SCA. So H5 was rejected. High-Performance work practice is positively and significantly related to sustainable competitive advantage. This means that hotel management activities that continuously encourage employees to work well, gain the latest knowledge is routinely done by conducting training and empowerment and awareness of large teamwork to understand each other's workload, especially when pandemic also rewarding, can help hotels compete competitively in the hospitality industry.

In this study Innovative behavior has no significant effect on sustainable competitive advantage. The result is difference from previous study conducted in Turkey, which was IB was having a significant effect to sustainable competitive advantage (Elidemir et al., 2020). We argue that the differences between these studies is more to the practical assessment of innovation for service firms with high customer physical interaction propensity. Due to the nearidentical nature of the services supplied, every company will set itself apart from competitors in 
Jurnal Bisnis dan Manajemen, Volume 22, No. 2, September 2021, p. 67-80

terms of its employees' attitudes on service performance, delivery, and experience. In Jakarta area, Hotel provides their own service rules that has specifics conditions to make hotel achieve differences on service performances between competitors, and these rules mitigate the IB on hotel's employees.

\section{Table 7. Indirect Effect}

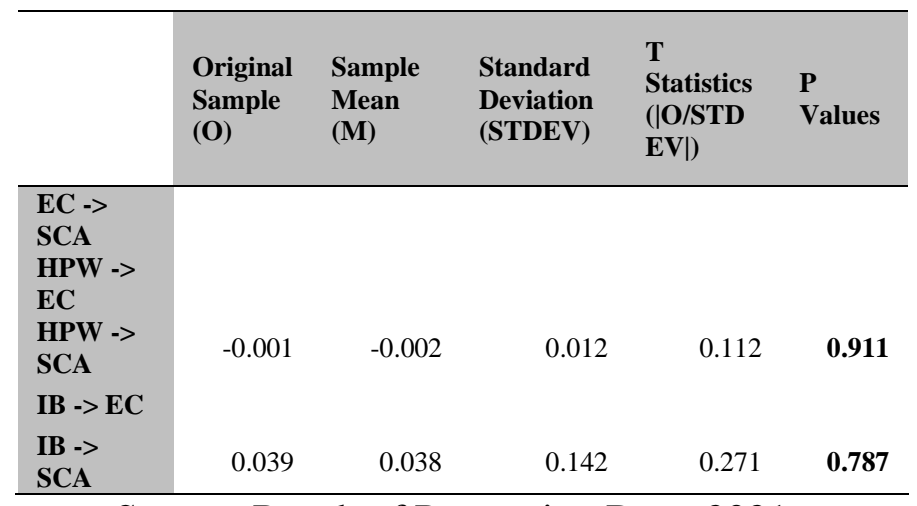

Source: Result of Processing Data, 2021.

HPW to SCA via EC has p value 0,911 > 0,05 , and IB to SCA via EC has p value of 0,787 $>0,05$ which means EC has no significant effect as a moderator to HPW and IB to SCA. SO H6, is rejected.

HPWs are especially promising for SCA with fewer creative staff that are more comfortable with established and traditional methods. In contrast, highly creative employees may experience workplace maladaptation as a result of limitations on their creative expression, which can lead to frustration with the job, the management, and coworkers. While this discovery contradicts what the literature suggests, innovation and creativity study evaluations acknowledged that in the current state of science, there are contradicting empirical findings (Hon \& Lui, 2016). Specifically, the success rate of innovation in the hotel industry is rather low (Ottenbacher, 2007), because of the risk of creativity/innovation, which is characterized by individuals/organizations deviating from traditional methods, causing them to adapt, think, and act in novel ways (Hon \& Lui, 2016). However, managers may be constrained by their inadequate knowledge and experience due to their fear of change, which is associated with risk-taking, uncertainty, and the potential for failure (Ottenbacher, 2007). As a result, they will limit and obstruct creative individuals, limiting and obstructing their employees' creative potential and degrading their competitive advantage (Caniëls \& Rietzschel, 2015).

\section{CONCLUSION}

Based on the study conducted on 100 employees of 4-star hotels in Jakarta can be concluded as follows; high-performances work practice is formed by indicators of training, empowerment, selective staffing, rewards and teamwork. Based on outer loadings, it was stated that the dominant indicators to high-performance work practice covered empowerment and training. For Employee creativity is formed by eight of valid indicators. From outer loadings, the dominant indicators suggest new ways to increase quality.

Innovative Behavior formed 6 items of indicators, which are innovative and creative notions, propose their own creative ideas and convince others, seek new service techniques, methods, or techniques, provide a suitable plan 
Jurnal Bisnis dan Manajemen, Volume 22, No. 2, September 2021, p. 67-80

for developing new ideas, secure the funding and resources needed to implement innovations, and considering themselves as creative members. From outer loading found out that the dominant indicators for innovative behavior are seek new service techniques, methods, or techniques and propose their own creative ideas and convince others. For sustainable competitive advantage formed by better products or services, managerial capability, good corporate image, and competitors are difficult to take the firm's competitive advantage. From outer loading the dominant indicators is managerial capability.

High-performance work practice runs in hotel industry, which is based on the research findings, indicates that high-performance work practice has a significant impact to employee creativity. The second finding is that hotel with innovative behavior of their employee also has a great impact to their employees' creativity. HPWP becomes a leverage in shaping employee creativity, the higher employee HPWP increases creativity among employees which in the end the linkage of these two aspects becomes capital for an organization to gain sustainable competitive advantage.

The third finding stated that the employee creativity in the hotel industry will significantly impact the sustainability competitive advantage of the company. Also, the fourth finding, support the proposed hypotheses' that high performance work practices in hotel will significantly impact the sustainable competitive advantage.
The fifth and sixth findings proved that there is no significant impact of innovative behavior on sustainable competitive advantage. Besides, employee creativity has no significant role as a moderator for High-Performance Work Practices (HPW), Innovative Behavior (IB), and Sustainable Competitive Advantage (SCA).

\section{MANAGERIAL IMPLICATIONS}

High performance work practice is important to be seen as a factor that will motivate innovative behavior and employee creativity. Employees in hotel came from many backgrounds that will enlighten the present workplace by sharing their experience in work. Therefore, it is essential idea for management to have a routine gathering for employees to share their knowledges and skills to others, so the hotel could make benefit of the experiences. With the unique creativity that pleases the guests, hotel will have many loyal customers who will keep coming and stays at the hotel. In this case, employees with their innovative behavior to the guests, and their creativity to make guest feel comfortable could support the sustainable competitive advantage in hotel industry.

\section{RESEARCH LIMITATIONS}

The limitation of this research is because this study's data was collected over such a short period of time, long-term observation cannot be ruled out. To sustain a competitive advantage in the highly competitive hospitality business, it is vital to assure the causal nature of the relationship between organizational learning and intellectual 
Jurnal Bisnis dan Manajemen, Volume 22, No. 2, September 2021, p. 67-80

capital. Thus, future research could examine the hypothesized model with longitudinal and experimental designs to further confirm whether HPW, IB and SCA are mediated by EC in hotel industry. Another limitation is that managers rated the measure constructs, so it's conceivable that they overlooked other factors that could have influenced the mutual ties in this study. Future research that accounts for favorable organizational performance, such as new service creation and financial performance, as well as additional measurement sources such as the employee or customer's perspective, could further rule out this issue.

\section{REFERENCES}

ÅMO, B. W., \& KOLVEREID, L. (2005). Organizational Strategy, Individual Personality and Innovation Behavior. Journal of Enterprising Culture, 13(01), 7-19. https://doi.org/10.1142/s0218495805000033

Armstrong, M. \& Taylor, S. (2014). Armstrong's handbook of human resource management practice (13th ed.). (13th editi). Kogan Page.

Awasthi, A., Dhawan, D., \& Soyav, M. (2020). Role of employee behaviour in hospitality industry. International Journal of Scientific and Technology Research, 9(1), 2208-2210.

Bakker, A. B., \& Demerouti, E. (2007). The Job Demands-Resources model: State of the art. Journal of Managerial Psychology, 22(3), 309328. https://doi.org/10.1108/02683940710733115

Boshoff, C. and Allen, J. (2000). The influence of selected antecedents on frontline staff's perceptions of service recovery performance", International Journal of Service Industry Management. 11(1), 63-90.

Caniëls, M. C. J., \& Rietzschel, E. F. (2015). Organizing creativity: Creativity and innovation under constraints. Creativity and Innovation Management, 24(2), 184-196. https://doi.org/10.1111/caim.12123

Chang, C. H. (2011). The Influence of Corporate Environmental Ethics on Competitive Advantage: The Mediation Role of Green
Innovation. Journal of Business Ethics, 104(3), 361-370. https://doi.org/10.1007/s10551-0110914-X

Colbert, B. A., \& Colbert, B. A. (2004). VIEW : THE COMPLEX RESOURCE-BASED AND FOR THEORY IMPLICATIONS PRACTICE IN STRATEGIC MANAGEMENT RESOURCE theoretical. The Academy of Management Review, 29(3), 341-358.

Connolly, P., \& McGing, G. (2007). High performance work practices and competitive advantage in the Irish hospitality sector. International Journal of Contemporary Hospitality Management, 19(3), 201-210. https://doi.org/10.1108/09596110710739903

Elidemir, S. N., Ozturen, A., \& Bayighomog, S. W. (2020). Innovative behaviors, employee creativity, and sustainable competitive advantage: A moderated mediation. Sustainability (Switzerland), 12(8). https://doi.org/10.3390/SU12083295

Evans, W. R., \& Davis, W. D. (2005). Highperformance work systems and organizational performance: The mediating role of internal social structure. Journal of Management, 31, 758-775.

Gant J., I. \& S. K. (2002). Social capital and organizational change in high involvement and traditional work organizations. Journal of Economics and Management Strategy, 11, 289328.

George, J. M. (2007). Creativity in organizations. Academy of Management, Annals, 1, 439-477.

George, Jennifer M., \& Zhou, J. (2001). When openness to experience and conscientiousness are related to creative behavior: An interactional approach. Journal of Applied Psychology, 86(3), 513-524. https://doi.org/10.1037/00219010.86.3.513

Ghozali, I., \& Latan, H. (2015). Partial Least Squares Concepts, Techniques and Applications using the SmartPLS 3.0 Program (Edition 2). Undip.

Hair, J. F., Risher, J. J., Sarstedt, M., \& Ringle, C. M. (2019). When to use and how to report the results of PLS-SEM. European Business Review, 31(1), 2-24. https://doi.org/10.1108/EBR-11-2018-0203

Hill, C.W.L.; Jones, G. R. (2009). Strategic Management: An Integrated Approach (9th ed.). South-Western Cengage Learning.

Hirst, G., van Knippenberg, D., \& Zhou, J. (2009). A CROSS-LEVEL PERSPECTIVE ON EMPLOYEE CREATIVITY: GOAL ORIENTATION, TEAM LEARNING BEHAVIOR, AND INDIVIDUAL 
Jurnal Bisnis dan Manajemen, Volume 22, No. 2, September 2021, p. 67-80

CREATIVITY. Academy of Management

Journal, 52(2), 280-293.

Hon, A. H. Y., \& Lui, S. S. (2016). Employee creativity and innovation in organizations: Review, integration, and future directions for hospitality research. International Journal of Contemporary Hospitality Management, 28(5), 862-885. https://doi.org/10.1108/IJCHM-092014-0454

Jeong, I., \& Shin, S. J. (2019). High-Performance Work Practices and Organizational Creativity During Organizational Change: A Collective Learning Perspective. Journal of Management, 45(3), 909-925.

https://doi.org/10.1177/0149206316685156

Li, M., \& Hsu, C. H. C. (2016). A review of employee innovative behavior in services. International Journal of Contemporary Hospitality Management Iss International Journal of Contemporary Hospitality Management, 28(12), 1-39. http://dx.doi.org/10.1108/IJCHM-04-20150214

Liu, C. H. (2017). Creating competitive advantage: Linking perspectives of organization learning, innovation behavior and intellectual capital. International Journal of Hospitality

Management, 66, 13-23. https://doi.org/10.1016/j.ijhm.2017.06.013

Luthans, F. (2005). Organizational Behaviour. McGraw-Hill.

Luthfia Ayu, A. (2020). Saat Pandemi Covid-19 Berdampak pada Bisnis Perhotelan Saat Ini. https://www.kompas.com/tren/read/2020/09/26/1 02900465/saat-pandemi-covid-19-berdampakpada-bisnis-perhotelan-saat-ini?page=all .

Mahdi, S. M., Sourchi, R., \& Liao, J. (2015).

Understanding High Performance Work System (HPWS) as Related to creativity and Job Engagement in Kurdistan and Canada. European Journal of Business and ManagementOnline), 7(20), 2222-2839.

Monica Hu, M. L., Horng, J. S., \& Christine Sun, Y. H. (2009). Hospitality teams: Knowledge sharing and service innovation performance. Tourism Management, 30(1), 41-50. https://doi.org/10.1016/j.tourman.2008.04.009

Ottenbacher, M. C. (2007). Innovation Management in the Hospitality Industry: Different Strategies for Achieving Success. Journal of Hospitality and Tourism Research, 31(4), 431-454. https://doi.org/10.1177/1096348007302352

Salguero, G. C., Gámez, M. Á. F., Fernández, I. A., \& Palomo, D. R. (2019). Competitive intelligence and sustainable competitive advantage in the hotel industry. Sustainability (Switzerland), 11(6), 1-12. https://doi.org/10.3390/su11061597

Sulaiman, I. F., Hashim, C. N., Ibrahim, M. B., Sariah, S., \& Hassan, S. (2015). Impact of Creativity to Organizational Competitiveness Kulliyyah of Education international Islamic University Jalan Gombak , 53100 Kuala Lumpur ,. International Journal of Humanities and Social Science, 5(8), 106-113.

SUNG-CHOON, KANG; SHAD S., MORRIS; SCOTT A., S. (2007). RELATIONAL ARCHETYPES, ORGANIZATIONAL LEARNING, AND VALUE CREATION: EXTENDING THE HUMAN RESOURCE ARCHITECTURE. Academy of Management Review, 32(1), 236-256.

https://doi.org/https://dx.doi.org/10.5465/amr.200 7.23464060

Vasudevan, H. (2013). The Influence of Emotional Intelligence and Creativity on Employee's Work Commitment and Performance. International Journal of Management and Business Research, 3(3), 233-255.

Wu, J., \& Chen, X. (2012). Leaders' social ties, knowledge acquisition capability and firm competitive advantage. Asia Pacific Journal of Management, 29(2), 331-350. https://doi.org/10.1007/s10490-011-9278-0 